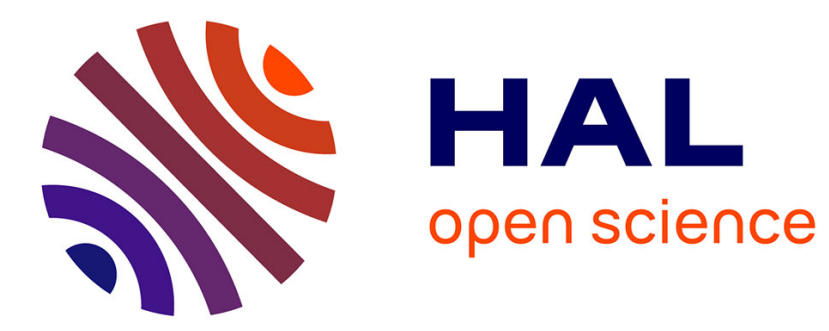

\title{
Bioaccumulation and Historical Deposition of Polybrominated Diphenyl Ethers (PBDEs) in Deep Bay, South China
}

Yao-Wen Qiu, Gan Zhang, Ling-Li Guo, Gene J. Zheng, Shu-Qun Cai

\section{- To cite this version:}

Yao-Wen Qiu, Gan Zhang, Ling-Li Guo, Gene J. Zheng, Shu-Qun Cai. Bioaccumulation and Historical Deposition of Polybrominated Diphenyl Ethers (PBDEs) in Deep Bay, South China. Marine Environmental Research, 2010, 70 (2), pp.219. 10.1016/j.marenvres.2010.05.004 . hal-00602616

\section{HAL Id: hal-00602616 https://hal.science/hal-00602616}

Submitted on 23 Jun 2011

HAL is a multi-disciplinary open access archive for the deposit and dissemination of scientific research documents, whether they are published or not. The documents may come from teaching and research institutions in France or abroad, or from public or private research centers.
L'archive ouverte pluridisciplinaire HAL, est destinée au dépôt et à la diffusion de documents scientifiques de niveau recherche, publiés ou non, émanant des établissements d'enseignement et de recherche français ou étrangers, des laboratoires publics ou privés. 


\section{Accepted Manuscript}

Title: Bioaccumulation and Historical Deposition of Polybrominated Diphenyl Ethers (PBDEs) in Deep Bay, South China

Authors: Yao-Wen Quu, Gan Zhang, Ling-Li Guo, Gene J. Zheng, Shu-Qun Cai

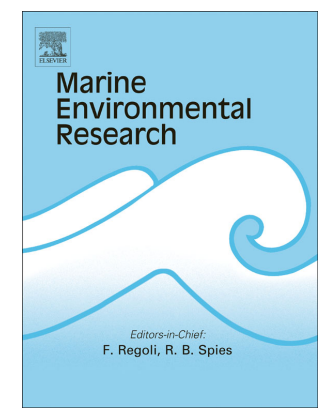

PII:

S0141-1136(10)00071-1

DOI:

10.1016/j.marenvres.2010.05.004

Reference: MERE 3451

To appear in: Marine Environmental Research

Received Date: 20 December 2009

Revised Date: 5 May 2010

Accepted Date: 10 May 2010

Please cite this article as: Qiu, Y.-W., Zhang, G., Guo, L.-L., Zheng, G.J., Cai, S.-Q. Bioaccumulation and Historical Deposition of Polybrominated Diphenyl Ethers (PBDEs) in Deep Bay, South China, Marine Environmental Research (2010), doi: 10.1016/j.marenvres.2010.05.004

This is a PDF file of an unedited manuscript that has been accepted for publication. As a service to our customers we are providing this early version of the manuscript. The manuscript will undergo copyediting, typesetting, and review of the resulting proof before it is published in its final form. Please note that during the production process errors may be discovered which could affect the content, and all legal disclaimers that apply to the journal pertain. 
1

\section{Bioaccumulation and Historical Deposition of Polybrominated}

\section{Diphenyl Ethers (PBDEs) in Deep Bay, South China} (1)

Yao-Wen Qiu ${ }^{\mathrm{a}, \mathrm{b},{ }^{*}}$, Gan Zhang ${ }^{\mathrm{b}}$, Ling-Li Guo ${ }^{\mathrm{b}}$, Gene J Zheng ${ }^{\mathrm{c}}$, Shu-Qun Cai ${ }^{\mathrm{a}}$ (1)

a. Key Laboratory of Tropic Marine Environmental Dynamics, South China Sea

Institute of Oceanology, Chinese Academy of Sciences, Guangzhou 510301, China;

b. State Key Laboratory of Organic Geochemistry, Guangzhou Institute of Geochemistry, Chinese Academy of Sciences, Guangzhou 510640, China;

c. Department of Biology and Chemistry, Centre for Coastal Pollution and Conservation, City University of Hong Kong, Tat Chee Avenue, Kowloon, Hong Kong, China;

${ }^{*}$ Corresponding author. Tel.: +86 208419 2756; fax: +86 2084451672.

E-mail address: yqiu@ scsio.ac.cn (Y.-W. Qiu). 
15

16

17

18

19

20

21

22

\section{Abstract}

To characterize the bioaccumulation and historical trends of polybrominated diphenyl ethers (PBDEs) in Deep Bay, an important water body between Hong Kong and mainland China with a Ramsar mangrove wetland (Maipo), marine organisms and core sediments were collected to determine their PBDEs concentrations. Sediment core dating was accomplished using the ${ }^{210} \mathrm{~Pb}$ method. PBDEs concentrations in fish ranged from 0.17 to $4.16 \mathrm{ng} \mathrm{g}^{-1}$ wet wt., with a mean value of $2.00 \mathrm{ng} \mathrm{g}^{-1}$ wet wt. Temporal trends of the target PBDE congeners levels in core sediment generally increased from 1948 to 2003, with the highest levels in top sediment, suggesting an ongoing PBDEs input. The average sedimentation flux of PBDEs was $0.25 \mathrm{ng} \mathrm{cm}^{-2} \mathrm{a}^{-1}$, and the double time of total PBDEs concentration was ca. 12.3 a. Correlations between the biota-sediment accumulation factors (BSAF) of PBDEs and their corresponding octanol-water partition coefficient $\left(K_{\text {ow }}\right)$ were discussed.

Keywords: Polybrominated diphenyl ethers; Benthos; Cores; Bioaccumulation; Stable isotopes; Deep Bay, South China. 


\section{Introduction}

Polybrominated diphenyl ethers (PBDEs) are the additive flame retardants and the next highest production group of brominated diphenyl ethers (BFRs) currently in use. PBDEs are widely used in manufactured products such as polymers, resins, electronic devices, building materials, textiles and polyurethane. PBDEs enter the environment via direct and indirect urban domestic/industrial sewage discharges and atmospheric deposition, and they have a tendency to accumulate in aquatic sediments and organisms due to their high octanol-water partition coefficients (Song et al., 2004). Some PBDE congeners exhibit substantially long environmental half-lives, potential bioaccumulation and possible adverse effects on wildlife and humans (de Wit, 2002; McDonald, 2002). They can impair attention, learning, memory and behavior in laboratory animals and possible interfer with early neurodevelopment (Fowles et al., 1994; Darnerud, 2003; Brigden et al., 2005).

PBDEs have been widely detected in air, water, sediment, organism, and humans in recent years. Their levels in biota were estimated to double every 5 years, and were reported to increase by 60-fold in human breast milk in Sweden between 1972 and 1997 (Meironyt and Bergman, 1999; de Wit, 2002; Law et al., 2006). The estimated domestic production of predominant commercial deca-BDE mixture in China increased by $200 \%$ between 2000 and 2005, from 10000 to about 30000 metric tons (Chen et al., 2007). Furthermore, China appears to be a large dumping site of e-wastes imported from overseas legally and illegally in recent years (Brigden et al., 2005; Guo et al., 2007). A previous study using skipjack tuna to elucidate the global distribution 
53

54

of PBDEs suggested that the coastal region off the East China Sea was supposedly a "hot spot" for PBDEs (Ueno et al., 2004). Apparently, the PBDEs contamination status in the environment of China and their effects on the ecosystem and humans remain to be fully understood.

Deep Bay, located in the eastern Lingdingyang of Pearl River Estuary, South China, is a natural, shallow estuarine bay with an average water depth of about $3 \mathrm{~m}$, and a tidal range of about $1.4 \mathrm{~m}$. It is $17.5 \mathrm{~km}$ long in SW-NE direction and $4 \sim 10 \mathrm{~km}$ in NW-SE direction (Fig. 1). The wetlands around Inner Deep Bay and Mai Po marshes are important to the migratory birds for many decades. The 1500 hectares of wetlands around the area was designated as a Wetland of International Importance under the Ramsar Convention in 1995. The consumption of PBDEs is believed to increase in this region because of the fast industrialization in the last two decades, which made the region the most important electronic manufacturing base in the world. Zheng et al. (2004) reported that the PBDE concentrations in green-lipped mussels from Hong Kong waters were among the highest in the world. Mai et al. (2005) reported that although the total PBDEs concentrations in sediments of the Pearl River Delta and adjacent South China Sea were mostly $<50 \mathrm{ng} / \mathrm{g}$, within the range for riverine and coastal sediments around the world, the BDE-209 concentrations at some sites were at the high end of the worldwide figures. Chen et al. (2007) investigated the time trend of PBDE concentration in sediment cores of Pearl River Estuary and results showed that total PBDEs (except for BDE 209) concentrations in all sediment cores increased gradually from the bottom (mid-1970s) to the middle layer (later 1980s and 
early 1990s). PBDEs residue levels in fish from South China had been also measured (Meng et al., 2007; Xiang et al., 2007; Guo et al., 2008). Recent study showed that there was a fresh DDT input into the bay (Qiu et al., 2009a). To our knowledge, few studies on PBDEs in Deep Bay have been conducted. The present work aimed to (1) study the bioaccumulation of PBDEs in organisms of Deep Bay; (2) investigate the chronology of PBDE concentration and flux in Deep Bay as recoded in sediment core based on the ${ }^{210} \mathrm{~Pb}$ dating; (3) analyze the compositions of PBDE congeners and the potential sources, and (4) discuss the relationships between the biota-sediment accumulation factors (BSAF) of PBDEs in Deep Bay and the corresponding octanol-water partition coefficient $\left(K_{\text {ow }}\right)$.

\section{Materials and methods}

\subsection{Samples collection}

Samples of benthic organisms and core sediment in seven stations from Deep Bay, as shown in Fig. 1, were collected in February 2004. A stainless steel static gravity corer ( $8 \mathrm{~cm}$ i.d.) was employed to collect the sediment which was sliced immediately at $1 \mathrm{~cm}$ intervals and stored in polyethene bags. The organism samples, with size ranging from $5 \mathrm{~cm}$ to $15 \mathrm{~cm}$ and lifespan approximately ranging $0.5-2$ a, were collected by benthic trawling and stored in polyethene bags. The organism samples from seven stations were mixed into one to represent organisms in Deep Bay as it was not easy to collect enough samples from each station. Since most of the fishes were small benthos fish, they should be considered as local fish. All samples were transported to the laboratory at about $0{ }^{\circ} \mathrm{C}$ and frozen at $-20^{\circ} \mathrm{C}$ prior to treatments. 
98 Fig. 1. Sampling locations in Deep Bay, South China

99

100 The specimens were identified in South China Institute of Oceanology, the Chinese

101 Academy of Sciences. These included planktivorous, omnivorous, and carnivorous

102 species, such as planktivorous fish (Clupanodon thrissa, Clupanodon punctatus,

103 Mugil cephalus), small carnivorous fish (Sillago japonica, Thrissa dussumieri,

104 Leiognathus bindus, Leiognathus ruconius, Ilisha elongate), carnivorous fish

105 (Inimicus cuvieri, Dasyatis zugei, Platycephalus indicus), benthos feeders

106 (Collichthys lucidus, Nibea acuta, Cynoglossus robustus), and omnivorous organisms

107 (Polynemus sextarius, Trypauchen vagina, Glossogobius giuris, Penaeus orientalis

108 and Portunus pubescens).

109 2.2. Chemical analysis

110 Samples preparation. Analytical procedures generally followed those of

111 Richardson and Zheng (1999) and Zheng et al. (2004). Frozen organism samples were

112 thawed and rinsed individually with purified water to remove possible impurities. The

113 edible parts from about 3-5 specimens of the same specimens (17 fishes, one shrimp

114 and one crab) collected from each location were pooled. Prior to extraction, the

115 organism and sediment samples were freeze-dried and homogenized. Subsamples

116 were dried to constant weight to determine the water contents. Dry samples were

117 ground into powder with a stainless steel blender. Approximately $10 \mathrm{~g}$ of powder was

118 placed in a round bottom flask, to which known quantities of ${ }^{13} \mathrm{C}$-labeled PBDE 
119

120

121

122

123

124

congeners (BDE-3, 15, 28, 47, 99, 153, and 183) were added. A hexane:acetone:dichloromethane (1:1:1) solution $(150 \mathrm{ml})$ was added, and heated to $65{ }^{\circ} \mathrm{C}$ to gently boil the sediment powder in solvent for $4 \mathrm{~h}$. After cooling, the mixture was filtered using a pre-cleaned glass filter, and the residue was washed three times with hexane and dichloromethane (total $30 \mathrm{ml}$ each solvent). For organism samples, an aliquot of one tenth was used to gravimetrically determine the lipid content and the left solution was treated with concentrated sulfuric acid $(5 \mathrm{ml} \times 3)$ to remove the bulk of lipids. The extraction solution both organism and sediment samples was reduced in volume to $1 \mathrm{ml}$ by rotary evaporation prior to column chromatography. A chromatography column consisting of $6 \mathrm{~g}$ of pre-activated silica gel and $1 \mathrm{~g}$ of activated copper powder was washed with $15 \mathrm{ml}$ acetone, followed by $15 \mathrm{ml}$ of dichloromethane and $20 \mathrm{ml}$ of hexane. The extraction aliquot $(1 \mathrm{ml})$ was then added on the column and the PBDEs were eluted with a $30 \mathrm{ml}$ mixture of dichloromethane and hexane (1:1), followed by $15 \mathrm{ml}$ of dichloromethane. The combined eluate (45 $\mathrm{ml})$ was reduced in volume to $300 \mu \mathrm{l}$ for quantitation by GC-MS spectrometry.

GC-MS analysis. PBDEs ( < octa-PBDE) were analyzed in all samples using a Varian Saturn 2200 Ion Trap GC/MS/MS with a 30 m DB-1 capillary column $(0.25$ $\mathrm{mm}$ diameter and $0.25 \mu \mathrm{m}$ film thickness), with helium at a rate of $1 \mathrm{ml} \mathrm{min}^{-1}$ as the carrier gas. BDE197, 207, 209 were analyzed with a similar but shorter column (10 m DB-1). The injector temperature was $280{ }^{\circ} \mathrm{C}$. The $\mathrm{GC}$ oven temperature was programmed as follows: $90{ }^{\circ} \mathrm{C}$ for 2 min, increasing $20{ }^{\circ} \mathrm{C}$ per minute to $230{ }^{\circ} \mathrm{C}$, followed by $2{ }^{\circ} \mathrm{C}$ per minute to $247^{\circ} \mathrm{C}$, then $20^{\circ} \mathrm{C}$ per minute to a final temperature 
141 of $280{ }^{\circ} \mathrm{C}$, which was held for $25 \mathrm{~min}$. The mass spectrometer was operated in the

142 electron impact/selected ion monitoring (EI/SIM) mode. PBDE concentrations in core

143 sediments (including BDE-17, 28, 32, 35, 37, 47, 49, 66, 71, 75, 77, 85, 99, 100, 119,

$144138,153,153,154,166,181,183$ and 190) and organisms (including BDE-3, 15, 28,

$14547,60,85,99,100,138,153,154,183,197,207$ and 209) were analyzed.

146 QA/QC. Retention times and mass spectra fragmentation for PBDEs 3, 15, 28, 47,

14799,153 , and 183 were established by using ${ }^{13} \mathrm{C}$-labeled PBDEs. Other PBDEs were

148 identified based on the literature. All samples were run in duplicate. Concentrations of

149 PBDEs in solvent blanks $(\mathrm{n}=2)$ were low $\left(<0.08 \mathrm{ng} \mathrm{g}^{-1}\right)$, and the samples were

150 considered valid when the concentrations exceeded three times that of the blank

151 values. All reported values were corrected with a mean value $\left(0.075 \mathrm{ng} \mathrm{g}^{-1}\right)$ of the

152 blanks. Solution spike recoveries ranged between 76\% (PBDE 183) and 108\% (PBDE 153 47).

154 Isotope analysis. The organism samples were analyzed for $\delta^{15} \mathrm{~N}$ using an elemental 155 analyzer EA (Flash EA 1112, CE) connected to an isotopic ratio mass 156 spectrometer-IRMS (Delta plus XL, Finnigan). Approximately $0.8 \mathrm{mg}$ of the sample 157 was weighed in a tin cup and combusted in the elemental analyzer. Samples and 158 standards were run in continuous flow with a standard deviation of $0.2 \%$ among 159 replicate standard samples.

160

161 162

\subsection{Sediment Dating}

Sediment core dating was accomplished via ${ }^{210} \mathrm{~Pb}$ analysis (Zhang et al., 2002; Qiu et al, 2009b). Briefly, the ${ }^{210} \mathrm{~Pb}$ activities in sediment sub-samples were determined by 
163 analysis of the $\alpha$-radioactivity of its decay product ${ }^{210} \mathrm{Po}$, on the assumption that the 164 two are in equilibrium. The Po was extracted, purified, and self-plated onto silver 165 discs at $75-80^{\circ} \mathrm{C}$ in 0.5 mole/ $\mathrm{L}$ of $\mathrm{HCl}$, with ${ }^{209} \mathrm{Po}$ (NIST, USA) used as yield monitor 166 and tracer in quantification. Counting was conducted by computerised multi-channel

$\alpha$-spectrometry with gold-silicon surface barrier detectors. Supported ${ }^{210} \mathrm{Po}$ was obtained by indirectly determining the $\alpha$-activity of the supporting parent ${ }^{226} \mathrm{Ra}$, which was carried by co-precipitated $\mathrm{BaSO}_{4}$. As the core did not reach the critical depth of excessive ${ }^{210} \mathrm{~Pb} \rightarrow 0$, only a Constant Initial ${ }^{210} \mathrm{~Pb}$ Concentration (CIC) model was used, which assumes that dry mass entering the sediment pool has the same radioactivity concentration, to give an average sedimentation rate. Sedimentation age was calculated using a constant flux (CF) model (McCall et al., 1984):

$$
t=-\lambda^{-1} \ln (1-\xi)
$$

where $\lambda$ is the radioactive decay constant for ${ }^{210} \mathrm{~Pb} \quad\left(0.03114 \mathrm{a}^{-1}\right)$, $\xi=\int_{0}^{g} A(g) d g / \int_{0}^{\infty} A(g) d g$, and $d \mathrm{~g}$ is the thickness of each sediment interval $\left(\mathrm{g} \mathrm{cm}^{-2}\right.$ $\left.\mathrm{a}^{-1}\right)$. For sediment cores, the three undisturbed cores $(\mathrm{A}, \mathrm{B}, \mathrm{E})$ were selected and analyzed for sediment dating. Since core A and E showed a mixing depth of ca. $7 \mathrm{~cm}$ and ca. $11.5 \mathrm{~cm}$, respectively, only core B (total $39 \mathrm{~cm}$ long) was eventually selected to determine the PBDEs concentrations. In general, PBDEs concentrations in Shenzhen River estuary (site A and F) are expected to be influenced more by sewage discharge, while PBDEs concentrations in the mouth of the bay (site E) are potential to be affected more by the runoff of Pearl River. The simultaneous study showed that concentrations of hydrophobic organic compounds such as polycyclic aromatic 
185

186

187

188

189

190

191

192

193

194

195

196

197

198

199

200

201

202

203

204

205

206

hydrocarbons in surface sediments of 7 sites (A, B, C, D, E, F and G) of Deep Bay were not significantly different (Qiu et al, 2009b). Moreover, Deep Bay is a relatively small bay and core B is located in the center of the bay. Therefore, it is reasonable to select core B as representing PBDEs distribution in the sediment of Deep Bay. Fig. S1 presents the distribution of excessive ${ }^{210} \mathrm{~Pb}$ activity in the core- $\mathrm{B}$, showing that the average sedimentation flux of the Core-B was $0.28 \mathrm{~g} \mathrm{~cm}^{-2} \mathrm{a}^{-1}$, with an apparent sedimentation rate of $0.69 \mathrm{~cm} \mathrm{a}^{-1}$.

\section{Results and Discussion}

\subsection{PBDEs in organisms}

The concentrations of 15 PBDE congeners (BDE-3, 15, 28, 47, 60, 85, 99, 100, 138, 153, 154, 183, 197, 207 and 209) in organisms, as well as their ${ }^{15} \mathrm{~N}$ values, are shown in Fig. 2. The mean total PBDEs concentrations in fish samples $\left(2.00 \pm 1.14 \mathrm{ng} \mathrm{g}^{-1}\right.$ wet wt.) were generally higher than those in shrimps (0.88 $\mathrm{ng} \mathrm{g}^{-1}$ wet wt.) and those in crabs (1.44 $\mathrm{ng} \mathrm{g}^{-1}$ wet wt.). PBDEs concentrations in wild fish of Deep Bay (mean: 2.00, 0.17-4.16 $\mathrm{ng} \mathrm{g}^{-1}$ wet wt. or mean: $62.9,20.9-166.4 \mathrm{ng} \mathrm{g}^{-1}$ lipid wt.) were higher than those wild fish of Daya Bay, South China (mean: 0.16, 0.04-0.70 $\mathrm{ng} \mathrm{g}^{-1}$ wet wt., Guo et al., 2008) and those in farmed fish of the coast of South China (mean: 0.15, $<0.0012-3.85 \mathrm{ng} \mathrm{g}^{-1}$ wet wt., Meng et al, 2007), but were lower than those wild biota in Pearl River Estuary where the median levels of the sum of BDEs 28, 47, 66, 85, 99, $100,138,153,154$, and 183 in large yellow croaker, silvery pomfret, flathead fish, robust tongue fish, and bombay duck were $67.3,123.9,114.4,181.2$, and $249.7 \mathrm{ng} \mathrm{g}^{-1}$ 
207

208

209

210

211

212

213

214

lipid wt., respectively (Xiang et al., 2007). This is consistent with the fact that Pearl River Estuary was more polluted than Daya Bay and Deep Bay. PBDEs concentrations in wild fish of Deep Bay were comparable to those in skipjack tunas Katsuwonus pelamis from offshore waters in Asia-Pacific regions and Indian Ocean $\left(<0.1-53 \mathrm{ng} \mathrm{g}^{-1}\right.$ lipid wt., Ueno et al. 2004) and those in farmed Atlantic salmon Salmo salar (0.49-10.92 $\mathrm{ng} \mathrm{g}^{-1}$ wet wt., Hites et al. 2004), but were lower than those in crappie Poxomis annularis and bluegill Lepomis macrochiras form Hadley Lake in the United States (1500-1900 $\mathrm{ng} \mathrm{g}^{-1}$ lipid wt., Dodder et al. 2002). In the present study, relatively higher total PBDE concentrations were observed in benthic fish (e.g., Cynoglossus robustus) and carnivorous fish (e.g., Inimicus cuvieri), while relatively lower PBDEs concentration was found in planktivorous fish (e.g., Mugil cephalus) indicating a positive correlation between fish PBDEs burden and their food habit.

Fig. 2. The PBDEs concentrations and $\delta^{15} \mathrm{~N}$ values in organisms collected from Deep Bay.

Increases in contaminant concentrations from the prey to the predator can be successfully defined using the relative abundances of naturally occurring stable isotopes of nitrogen (i. e., $\delta^{15} \mathrm{~N}$ values; Hobson and Welch, 1992). The increase in $\delta^{15} \mathrm{~N}$ is generally 3 to $5 \%$ o between each trophic level (Minigawa and Wada, 1984), though a consumer's diet often consists of prey organisms from different trophic levels, depending on the availability of prey organisms (Ruus et al, 2002). In the present study, planktivorous fish Mugil cephalus showed a lower $\delta^{15} \mathrm{~N}$ value $(7.1 \%$ o 
229

230

231

232

233

234

235

236

237

than carnivorous fish Inimicus cuvieri (14.4\%o) in Deep Bay. As shown in Fig. 2, positive correlations between total PBDEs (normalized to lipid content) and $\delta^{15} \mathrm{~N}$ values in planktivorous fish were apparently observed, whereas negative correlations between them in small carnivorous fish were also found. Relationships between log PBDEs (ng/g lipid wt.) and $\delta^{15} \mathrm{~N}$ values in the organisms of Deep Bay were shown in Fig. 3-a. The same pattern was also observed for BDE-47. A weak bioaccumulation of hydrophobic chemicals in organism of the tropical-subtropical waters may be interpreted by enhanced partition of hydrophobic chemicals between water and organisms due to higher temperature, as well as by relatively quick metabolism and short resident time of the chemicals in organisms (Guo et al., 2008). There was a significant correlation between log PBDEs (ng/g wet wt.) and log percent lipid in the organisms from Deep Bay $\left(R^{2}=0.54 ; P<0.01\right.$; Fig. $\left.3-\mathrm{b}\right)$, confirming the fact that PBDEs are hydrophobic in nature and easily bioaccumulated in organisms.

Fig. 3. The relationships between PBDEs concentrations and $\delta^{15} \mathrm{~N}$ values and lipid percents in organisms from Deep Bay

\subsection{PBDE in core sediment}

Total $\Sigma_{22}$ PBDEs (BDE-17, 28, 32, 35, 37, 47, 49, 66, 71, 75, 77, 85, 99, 100, 119, $138,153,153,154,166,181,183$ and 190) concentrations in the core sediment from Deep Bay ranged from 0.07 to $4.85 \mathrm{ng} / \mathrm{g}$ dry wt, with median value of $0.68 \mathrm{ng} / \mathrm{g}$ dry wt (or $65 \mathrm{ng} / \mathrm{g}$ organic carbon). In the neighboring area, i.e. the Pear River Estuarine 
251

252

253

254

255

256

257

258

259

260

261

262

263

264

265

266

267

region (Mai et al, 2005), the average concentration of BDE-209 in surface sediment was $18.5 \mathrm{ng} / \mathrm{g}$ (range: $0.7-111.9 \mathrm{ng} / \mathrm{g}$ ), while the sum of 10 PBDE congeners (BDE-28, -47, -66, -100, -99, -138, -153,-154, -183) concentrations in surface sediments was $3.13 \mathrm{ng} / \mathrm{g}$ (range: $0.3-21.8 \mathrm{ng} / \mathrm{g}$ ), which was higher than those in Deep Bay for the same 10 congeners $(2.22 \mathrm{ng} / \mathrm{g})$. Total $\Sigma_{22}$ PBDEs levels in surface sediments in the present study ( $3.31 \mathrm{ng} / \mathrm{g}$ dry $\mathrm{wt}$, top $2 \mathrm{~cm}$ in core sediment) were generally comparable to those in surface sediment samples collected in Pearl River Estuary of South China (0.11-13.03 ng/g, Zheng et al., 2004), those in the coastal region of Korea (1.1-33.8 ng/g, Moon et al., 2002), and those in the river and coastal areas of Portugal (0.5-20 ng/g, Lacorte et al., 2003), but were generally lower than those in Osaka Bay of Japan (8-352 ng/g, Ohta et al., 2002) and those in San Francisco Estuary of US (BDL-212 ng/g, Oros et al., 2005). PBDEs levels in surface sediment in Deep Bay were generally at the low-intermediate ranges in the world.

The down-core variations of PBDE concentrations and TOC contents in the core as a function of the deposition year are shown in Fig. 4. In general, the levels of PBDE congeners started to increase from the late 1960s onward and reached the second highest values in 1990s and the highest values in 2003 (top layer). These increases coincided with the production and usage figures of penta-mixture in the world since the 1970s. The second peak PBDE concentrations occurred in the 1990s, which might indicate a critical time for the widespread use of the BFR-related substances in Pearl River Delta. There was a continuous and obvious increase of PBDEs concentrations toward the surface layer after 1982, suggesting the fresh PBDEs inputs into Deep Bay. 
273 Similar distribution profiles have been also observed in the sediment cores from

274 Macao (Chen et al, 2007), Osaka Bay (Sakai et al. 2002), Western Europe (Zegers et 275 al., 2003) and the Great Lakes (Song et al., 2004). While different patterns occurred in 276 the sediment cores of Tokyo Bay where PBDEs levels increased up to the mid-1990s 277 and decreased afterwards (Minh et al., 2007). In addition, the absence of all PBDE 278 congeners in the older layers (before the late 1950s) in the present study indicated the 279 absence of natural production of the target BDE congeners. This situation also 280 occurred in sediment cores from the Drammenfjord (Norway), the western Wadden 281 Sea (The Netherlands), and the freshwater Lake Woserin (Germany) (Zegers et al., 282 2003). The apparent early arrival of PBDEs (late 1950s) in present study might 283 actually reflect bioturbation, which can move contaminants deeper into the core.

Fig. 4. PBDE concentrations in the sediment core by year of deposition

287 Based on ${ }^{210} \mathrm{~Pb}$ dating results, the current sedimentation flux of PBDEs was $0.92 \mathrm{ng}$ $288 \mathrm{~cm}^{-2} \mathrm{a}^{-1}$, with the average of $0.25 \mathrm{ng} \mathrm{cm}^{-2} \mathrm{a}^{-1}$. In order to understand the pollution rate, 289 the time required for the concentration of PBDEs to double (T2) was estimated from 290 data measured in sediment core from Deep Bay. The T2 value of PBDEs 291 concentrations was 12.3 a $\left(\mathrm{r}^{2}=0.80\right)$, which was longer than those in sediment cores 292 from the adjacent Pearl River Estuary (T2=6 7 a, Chen et al., 2007), but was 293 comparable to those in Lake Michigan of US (T2=11.2 a, Zhu et al., 2005). The T2 294 value in the present study was approximately 1-2 folds higher than the 4-6 a reported 
295 for biota and humans (Hites, 2004).

296 Due to their high hydrophobic properties, PBDE congeners are expected to be

297 associated mainly with the organic carbon-rich particles in the sediment. In the 298 present sediment core, total organic carbon (TOC) contents ranged from $0.67 \%$ to $2991.41 \%$, with an average of $1.01 \%$. Statistical analysis showed that TOC contents 300 explained $52 \%$ of the variability in total PBDEs concentrations, implying the role 301 played by organic matters in the transport and redistribution of PBDEs in Deep Bay.

\subsection{Compositions and Sources}

Among the 15 PBDEs (BDE-3, 15, 28, 47, 60, 85, 99, 100, 138, 153, 154, 183, 197 ,

207 and 209) measured in organisms in the present study, BDE-47 and BDE-100 were the predominant congeners, accounting for $46.5 \%$ and $13.5 \%$ of total PBDEs in organisms from Deep Bay, respectively (Fig. S2-a). This is consistent with the fact that BDE-47 and BDE-100 are the most bioaccumulative congeners among the commercial Penta-BDE mixtures (Oros et al., 2005). It is noteworthy that, despite the large quantity of BDE-209 used in Asia/China (Ueno et al., 2004) as well as its high concentrations in some of the sediments from the Pearl River Delta (Mai et al., 2005), BDE-209 comprised only $<1.3 \%$ of the total PBDEs in the organisms of Deep Bay. This may imply that BDE-209 has a low bioaccumulation potential to organisms

313 (Boon et al., 2002; Guo et al., 2008). 
317

318

$21.4 \%, 10.9 \%, 13.8 \%$ and $17.4 \%$ of total PBDEs concentrations, while in surface sediment (top $2 \mathrm{~cm}$ ) they accounted for $30.6 \%, 13.9 \%, 14.0 \%$ and $7.2 \%$ of total PBDEs concentrations, respectively (Fig. S2-b). It should be noted that BDE-209 was the most predominant congener in sediment of the adjacent Pearl River Estuary, accounting approximately $86 \%$ of total PBDEs (Mai et al., 2005). In the present study, BDE-47 and BDE-49 in surface sediments were higher than the average values in sediment core, whereas BDE-183 was on the contrary. Recent studies showed that octa-BDE (BDE-196, -197 and -203) can be debrominated to hepta-BDE 183, and hexa-BDE 153, as well as the two most commonly detected PBDEs in the environment, penta-BDE 99 and tetra-BDE 47, by anaerobic dehalogenating bacteria (Robrock et al., 2008). Our results suggest that some proportion of BDE-183 in sediment core may be produced in situ by debromination, but not for BDE-47 and BDE-49. Environmental debromination in sediments was not evident in Deep Bay. The same pattern was also observed on the west coast of Canada (Johannessen et al., 2008). In general, highly brominated congeners can be transformed to lower brominated congeners or metabolites, which could become an important source of low brominated BDEs in the environment (Keum and Li, 2005).

Previous studies showed that BDE-47 and BDE-99 were the most common congeners in air, water, and sediment, as well as in people, fish, birds, and mammals (de Wit, 2002; Watanabe and Sahai, 2003; Law et al., 2006). The pattern of the major congeners in sediment from Deep Bay remained similar to that of the industrial formulation Bromkal 70-5DE, which may be related to the widely used penta- and 
339

340

341

342

343

344

octa-BDE commercial products and is probably the original source. For example, BDE-99 is a major component in penta-BDE commercial products $(48.6 \%$ in DE-71 [Great Lakes Chemical] and 44.8\% in Bromkal 70-5DE [Chemische Fabrik Kalk], La-Guardia et al., 2006), and in the present study, its relative abundance in the core samples was $13.8 \%$. Compared to those in other environmental compartments of local areas, the proportion of BDE-99 in core sediment of Deep Bay was lower than those in water of Pearl River (27\%, Guan et al., 2007), air of Gunagzhou (28\%, Chen et al., 2006), and sediments of the Pearl River Delta and northern South China Sea (38\%, Mai et al., 2005). BDE-47 is another abundant congener in penta-BDE products (38.2\% in DE-71 and 42.8\% in Bromkal 70-5DE, La-Guardia et al., 2006), and was predominant in all samples, with a mean percentage content of $24 \%$, which was generally close to those in riverine runoff (35\%, Guan et al., 2007), air (39\%, Chen et al., 2006), and sediments (28\%, Mai et al., 2005). BDE-183, considered as a marker compound for the octa-mix PBDE formulation (42\% in DE-79; Great Lakes Chemical; La-Guardia et al., 2006), was also found in the core sediment of Deep Bay at relatively high median concentrations, equivalent to $0.12 \mathrm{ng} / \mathrm{g}$ ( $15 \%$ of total PBDEs), suggesting the extensive use of technical octa-BDEs in local areas. The high proportion of BDE-183 (8\%-16\%) in the waterbirds of South China has also been reported (Luo et al., 2009). These results were completely different from those in three cores collected from Western Europe where BDE183 was systematically absent (Zegers et al., 2003). E-waste and waste discharges in surrounding areas were reported as the potential sources (Mai et al., 2005; Wu et al., 2008). 
In core sediment, significant positive correlations were found among PBDE

362

363 congeners except for BDE-181, -166 and -71 which were at very low levels (Table S1), suggesting that these congeners had similar source inputs and underwent similar deposition and decomposition processes. Principal component analysis (PCA) showed that the first two factors accounted for $75 \%$ of the total variance in the dataset (Fig. S3). Tri- to penta-BDE congeners primarily contributed to factor 1 which explained $63 \%$ of the total variance, indicating that these contaminants may originate from penta-BDE commercial products and their metabolites. Hexa- and hepta-BDEs formed another group and contributed primarily to factor 2. They might have been formed from the mixed octa-BDE products and by the degradation of deca-BDE through microorganism and photolysis (Söderström et al., 2004; Gerecke et al., 2005). Correlations among PBDE congeners in organisms are also summarized in Table S2 and Fig. S4.

\subsection{BSAF of PBDE}

Hydrophobic and lipophilic organic contaminants can easily accumulate in organisms such as fish mainly via bioconcentration directly from the water environment (LeBlanc, 1995), and/or biomagnification through trophic transfer (Kiriluk et al., 1995). Aquatic organism especially benthic organisms can absorb contaminants from sediment, and its ability can be expressed by the biota-sediment accumulation factors (BSAF), defined as a ratio of the lipid-normalized concentration of the chemical in tissue and the organic carbon-normalized concentration of the chemical in sediment. In this study, we selected the PBDE congeners measured both 
383

384

385

386

387

388

389

390

391

392

393

394

395

396

397

398

399

400

401

402

403

404

in organisms and sediment (top $2 \mathrm{~cm}$ ) to calculate the BSAF for individual PBDE congeners in each specimen. Individual BDE congeners with descending values of BSAFs (in parentheses) for all specimens in Deep Bay followed the sequence of BDE-100 (0.72) > BDE-154 (0.68) > BDE-85 (0.48) > BDE-153 (0.39) > BDE-28 $(0.30)>$ BDE-47 (0.29) > BDE-138 (0.016) > BDE-183 (0.014) > BDE-99 (0.001). In the adjacent Pear River Estuary (Xiang et al, 2007), the median values of BSAF for biota followed the sequence of BDE-100 (17.35) > BDE-47 (11.18) > BDE-154 (4.49) > BDE-99 (3.36) > BDE-66 (2.81) > BDE-153 (2.58) > BDE-28 (1.46) > BDE-183 $(0.04)>$ BDE-138 (0.00) > BDE-209 (0.00). In Deep Bay and Pearl River Estuary, the highest BSAF value was BDE-100 while the lower BSAF values were BDE-138 and BDE-183. The BASF values of the target PBDE congeners $(<0.8)$ in the present study were lower than those in fish from the lakes of the northeastern United States (16-38, Dodder et al., 2002), suggesting a weaker bioaccumulation of PBDE in organisms of Deep Bay. The relatively longer age (3-4 a) of the target fish (Pomoxis annularis and Lepomis macrochirus) in the above study may partly contribute the higher BASF values. Correlations between the BSAF of PBDE and the corresponding $K_{\text {ow }}$ in Deep Bay were shown in Fig. 5. As the bromine substituted number of PBDE congener increases, the corresponding $K_{\mathrm{ow}}$ and hydrophobic properties increase, leading to the higher ability for bioaccumulating contaminants. On the other hand, as the bromine substituted number of PBDE congener increases, the molecular volume and the steric effect also increase, resulting in a lower ability for bioaccumulating contaminants. In the present study, 3-6 Br PBDE except for BDE-99 and BDE-138 had the higher 
405

406

407

408

409

410

411

412

413

414

415

416

417

ability of bioaccumulation, while Dodder et al. (2002) reported that 4-6 Br PBDE in fishes from the northeastern United States had the higher ability of bioaccumulation.

It was reported that the maximum bioaccumulation for PBDE in British Columbia grizzly bears was found to be in the mid-range of PBDE $\log K_{\text {ow }}$ (Christensen et al., 2005).

Fig. 5. The biota-sediment accumulation factors (BSAF) of PBDE congeners in Deep Bay and their relation with the logarithm of octanol-water partition coefficient $\left(K_{\text {ow }}\right)$

\section{Conclusions}

In this paper, we provide detailed information about PBDEs in benthos and core sediment of Deep Bay, South China. The PBDEs concentrations in benthic organisms were at intermediate levels compared with those reports in other parts of the world. BDE-47 was the most predominant congener in both organisms and core sediments (not including BDE-209 in sediment), accounting for $46.5 \%$ and $21.4 \%$ of total target PBDEs, respectively. Owing to the recent rapid regional economic development, PBDEs contamination in the bay revealed increasing time trends in core sediment, suggesting an ongoing PBDEs input into the bay. E-waste and waste discharges may be the potential sources of contamination in Deep Bay.

\section{Acknowledgments}

This work was funded by National Natural Science Foundation of China (No. 
427

428

429

430

431

432

433

434

435

436

437

438

439

440

441

442

443

444

445

446

447

448

40821003 and No.40573061) and the commonwealth project from the State Oceanic

Administration of China (No.200705026). We thank the anonymous reviewers for their kind constructive suggestions on the manuscript.

\section{Supporting Information}

Table S1. Correlations between PBDE congeners and total organic carbon (TOC) in core sediments of Deep Bay, South China

Table S2. Correlations between PBDE congeners and lipid contents in organisms of Deep Bay, South China

Fig. S1. Distribution of sedimentation age and excessive $210 \mathrm{~Pb}$ activity in the sediment core B

Fig. S2. The percentage of PBDE congeners in organism and sediment of Deep Bay, South China

Fig. S3. Rotated factor pattern for PBDEs in core sediments of Deep Bay, South China

Fig. S4. Rotated factor pattern for PBDEs in organisms of Deep Bay, South China

\section{References}

Boon, J.P., Lewis, W.E., Tjoen-A-Choy, M.R., Allchin, C.R., Law, R.J., De Boer, J., Ten Hallers-Tjabbes, C.C., Zegers, B.N., 2002. Levels of polybrominated diphenyl ether (PBDE) flame retardants in animals representing different trophic levels of the North Sea food Web. Environmental Science and Technology 36, 4025-4032.

Brigden, K., Labunska, I., Santillo, D., Allsopp, M., 2005. Recycling of electronic wastes in China and India: workplace and environmental contamination. 
Chen, L.G., Mai, B.X., Bi, X.H., Chen, S.J., Wang, X.M., Ran, Y., Luo, X.J., Sheng, G.Y., Fu, J.M., Zeng, E.Y., 2006. Concentration levels, compositional profiles, and gas-particle partitioning of polybrominated diphenyl ethers in the atmosphere of an urban city in South China. Environmental Science and Technology 40, 1190-1196.

Chen, S.J., Luo, X.J., Lin, Z., Luo, Y., Li, K.C., Peng, X.Z., Mai, B.X., Ran, Y., Zeng, E.Y., 2007. Time Trends of Polybrominated Diphenyl Ethers in Sediment Cores from the Pearl River Estuary, South China. Environmental Science and Technology 41, 5595-5600. Organic Pollutants in British Columbia Grizzly Bears: Consequence of Divergent Diets.

de Wit, C.Y., 2002. An overview of brominated flame retardants in the environment. Environmental Science and Technology 39, 6952-6960.

Darnerud, P. O., 2003. Toxic effects of brominated flame retardants in man and wildlife. Environment International 29, 841-853.

Chemosphere 46, 583-624.

Dodder, N.G., Strandberg, B., Hites, R.A., 2002. Concentrations and spatial variations of polybrominated diphenyl ethers and Several Organochlorine Compounds in fishes from the northeastern United States. Environmental Science and Technology 36, 146-151. endocrine effects of the flame retardant pentabromodiphenyl ether (DE-71) in C57BL/6J mice. Toxicology 86, 49-61. 
471 Gerecke, A.C., Hartmann, P.C., Heeb, N.V., Kohler, H.P., Giger, W., Schmid, P., Zennegg, M.,

472 Kohler, M., 2005. Anaerobic degradation of decabromodiphenyl ether. Environmental Science 473 and Technology 39, 1078-1083.

474 Guan, Y.F., Wang, J.Z., Ni, H.G., Luo, X.J., Mai, B.X., Zeng, E.Y., 2007. Riverine fluxes of 475 polybrominated diphenyl ethers from the Pearl River Delta (China) to the coastal ocean. Environmental Science and Technology 41, 6007-6013.

Guo, J.Y., Wu, F.C., Mai, B.X., Luo, X.J., Zeng, E.Y., 2007. Polybrominated Diphenyl Ethers in Seafood Products of South China. Journal of Agricultural and Food Chemistry 55, 9152-9158.

Guo, L.L., Qiu, Y.W., Zhang, G., Zheng, G.J., Lam, P.K.S., Li, X.D., 2008. Levels, compositions and bioaccumulation of organochlorine pesticides (OCPs) and polybrominated diphenyl ethers (PBDEs) in fishes in the Pearl River estuary and Daya Bay, South China.

Hites, R.A., 2004. Polyhrominated diphenyl ethers in the environment and in people: A meta-analysis of concentrations. Environmental Science and Technology 38, 945-956.

Hites, R.A., Foran, J.A., Schwager, S.J., Knuth, B.A., Hamilton, M.C., Carpenter, D.O., 2004. Global Assessment of Polybrominated Diphenyl Ethers in Farmed and Wild Salmon. Environmental Science and Technology 38, 4945-4949.

Hobson, K.A., Welch, H.E., 1992. Determination of trophic relationships within a high Arctic marine food web using $\delta 13 \mathrm{C}$ and $\delta 15 \mathrm{~N}$ analysis. Marine Ecology Progress Series 84, 9-18.

Johannessen, S.C., Macdonald, R.W., Wright, C.A., Burd, B., Shaw, D.P., van Roodselaar, A., 2008. Joined by geochemistry, divided by history: PCBs and PBDEs in Strait of Georgia sediments. Marine Environmental Research 66, 112-120. 
493 Keum, Y.S., Li, Q.X., 2005. Reductive debromination of polybrominated diphenyl ethers by

494 zerovalent iron. Environmental Science and Technology 39, 2280-2286.

495 Kiriluk, R.M., Servos, M.R., Whittle, D.M., Cabana, G., Rasmussen, J.B., 1995. Using stable

496 nitrogen and carbon isotopes to characterize the biomagnification of DDE, mirex, and PCB in

497 Lake Ontario pelagic food web. Canadian Journal of Fisheries and Aquatic Sciences 52, $498 \quad 2660-2674$.

499 Lacorte, S., Guillamón, M., Martínez, E., Viana, P., Barceló, D., 2003. Occurrence and specific 500 congener profile of 40 polybrominated diphenyl ethers in river and coastal sediment from $501 \quad$ Portugal. Environmental Science and Technology 37, 892-898.

502 La-Guardia, M.J., Hale, R.C., Harvey, E., 2006. Detailed polybrominated diphenyl ether (PBDE) congener composition of the widely used penta-, octa-, and deca-PBDE technical flame-retardant mixtures. Environmental Science and Technology 40, 6247-6254.

Law, R.J., Allchin, C.R., de Boer, J., Covaci, A., Herzke, D., Lepom, P., Morris, S., Tronczynski, J., de Wit, C.A., 2006. Levels and trends of brominated flame retardants in the European

LeBlanc, G.A. 1995. Trophic level differences in the bioconcentration of chemicals: implications $154-160$.

Luo, X.J., Zhang, X.L., Liu, J., Wu, J.P., Luo, Y., Chen, S.J., Mai, B.X., Yang, Z.Y., 2009. Persistent Halogenated Compounds in Waterbirds from an e-Waste Recycling Region in South China. Environmental Science and Technology 43, 306-311. 
515

516

E.Y., 2005. Distribution of polybrominated diphenyl ethers in sediments of the Pearl River Delta and adjacent South China Sea. Environmental Science and Technology 39, 3521-3527.

McCall, P.L., Robbins, J.A., Matiso, G., 1984. 137Cs and 210Pb transport and geochronologies in urbanized reservoirs with rapidly increasing sedimentation rates. Chemical Geology 44, $33-65$.

McDonald, T.A., 2002. A perspective on the potential health risks of PBDEs. Chemosphere 46, $745-755$.

Meironyt, D., Bergman, A., 1999. Analysis of Polybrominated Diphenyl Ethers in Swedish Human Milk, 1972-1997. Journal of Toxicology and Environmental Health, Part A 58, $329-341$.

Minh, N.H., Isobe, T., Ueno, D., Matsumoto, K., Mine, M., Kajiwara, N., Takahashi, S., Tanabe, S., 2007. Spatial distribution and vertical profile of polybrominated diphenyl ethers and hexabromocyclododecanes in sediment core from Tokyo Bay, Japan. Environmental Pollution $148,409-417$.

Minigawa, M., Wada, E., 1984. Stepwise enrichment of 15N along food chains: Further evidence and the relation between $\delta 15 \mathrm{~N}$ and animal age. Geochimica et Cosmochimica Acta 48, $1135-1140$.

Moon, H., Chio, H., Kim, S., Jeong, S., Lee, P., Ok, G., 2002. Contaminations of polybrominated diphenyl ethers in marine sediments from the southeastern coastal areas of Korea. Organohalogen Compounds 58, 217-220.

Oros, D.R., Hoover, D., Rodigari, F., Crane, D., Sericano, J., 2005. Levels and distribution of polybrominated diphenyl ethers in water, surface sediments, and bivalves from the San 
Ohta, S., Nakao, T., Nishimura, H., Okumura, T., Aozasa, O., Miyata, H., 2002. Contamination levels of PBDEs, TBBPA, PCDDs/DFs, PBDDs/DFs, and PXDDs/Fs in the environment of Japan. Organohalogen Compounds 57, 57-60.

Qiu, Y.W., Zhang, G., Guo, L.L., Cheng, H.R., Wang, W.X., Li, X.D., Onyx, W.H. Wai., 2009a. South China. Estuarine, Coastal and Shelf Science 85, 265-272.

Qiu, Y.W., Zhang, G., Liu, G.Q., Guo, L.L., Li, X.D., Onyx, W.H. Wai., 2009b. Polycyclic Japan. Organohalogen Compounds 58, 189-192. aromatic hydrocarbons (PAHs) in the water column and sediment core of Deep Bay, South China. Estuarine, Coastal and Shelf Science 83, 60-66.

Richardson, B.J., Zheng, G.J., 1999. Chlorinated hydrocarbon contaminants in Hong Kong sediments. Chemosphere 39, 61-71.

Robrock, K.R., Korytár, P., Alvarez-Cohen, L., 2008. Pathways for the Anaerobic Microbial Debromination of Polybrominated Diphenyl Ethers. Environmental Science and Technology $42,2845-2852$.

Ruus, A., Ugland, K.I., Espeland, O., Skaare, J.U., 2002. Influence of trophic position on organochlorine concentrations and compositional patterns in a marine food web. Environmental Toxicology and Chemistry 21, 2356-2364.

Sakai, S., Hayakawa, K., Okamoto, K., Takatuki, H., 2002. Time trends and horizontal distribution of polybrominated diphenyl ethers (PBDEs) in sediment cores from Osaka Bay,

Söderström, G., Sellström, U., de Wit, C.A., Tysklind, M., 2004. Photolytic Debromination of 

diphenyl ethers in the sediments of the Great Lakes. 1. Lake Superior. Environmental Science and Technology 38, 3286-3293.

Watanabe, I., Sahai, S.I., 2003. Environmental release and behavior of brominated flame retardants. Environment International 29, 665-682. Muchitar, M., Razak, H., Prudente, M., Chun, K.H., Tanabe, S., 2004. Global pollution monitoring of polybrominated diphenyl ethers using skipjack tuna as a bioindicator. Environmental Science and Technology 38, 2312-2316.

Wu, J.P., Luo, X.J., Zhang, Y., Chen, S.J., Mai, B.X., Yang, Z.Y., 2008. Bioaccumulation of polybrominated diphenyl ethers (PBDEs) and polychlorinated biphenyls (PCBs) in wild aquatic species from an electronic waste (e-waste) recycling site in South China. Environment International 34, 1109-1113.

Xiang, C.H., Luo, X.J., Chen S.J., Yu, M., Mai, B.X., Zeng, E. Y., 2007. Polybrominated diphenyl ethers in biota and sediments of the Pearl River Estuary, South China. Environmental Toxicology and Chemistry 26, 616-623.

Zegers, B.N., Lewis, W.E., Booij, K., Smittenber, R.H., Boer, W., de Boer, J., Boon, J.P., 2003. Levels of polybrominated diphenyl ether flame retardants in sediment core from western Europe. Environmental Science and Technology 37, 3803-3807.

Zheng, G.J., Martin, M., Richardson, B.J., Yu, H., Liu, Y., Zhou, C., Li, J., Hu, G., Lam, M.H.W., Lam, P.K.S., 2004. Concentrations of polybrominated diphenyl ethers (PBDEs) in Pearl River 
Delta sediments. Marine Pollution Bulletin 49, 514-524.

582 Zhu, L.Y., Hites, R.A., 2005. Brominated flame retardants in sediment cores from Lakes Michigan and Erie. Environmental Science and Technology 39, 3488-3494. 


\section{Figures:}

588 Fig. 1. Sampling locations in Deep Bay, South China.

589 Fig. 2. The PBDEs concentrations and $\delta^{15} \mathrm{~N}$ values in organisms collected from 590 Deep Bay.

591 Fig. 3. The relationships between PBDEs concentrations and $\delta^{15} \mathrm{~N}$ values and lipid 592 percents in organisms from Deep Bay.

593 Fig. 4. PBDE concentrations in the sediment core by year of deposition (BDE209 594 was not included in the total PBDEs).

595 Fig. 5. The biota-sediment accumulation factors (BSAF) of PBDE congeners in 596 Deep Bay and their relation with the logarithm of octanol-water partition coefficient $597\left(K_{\text {ow }}\right)$. 
599 Fig. 1. Sampling locations in Deep Bay, South China

600

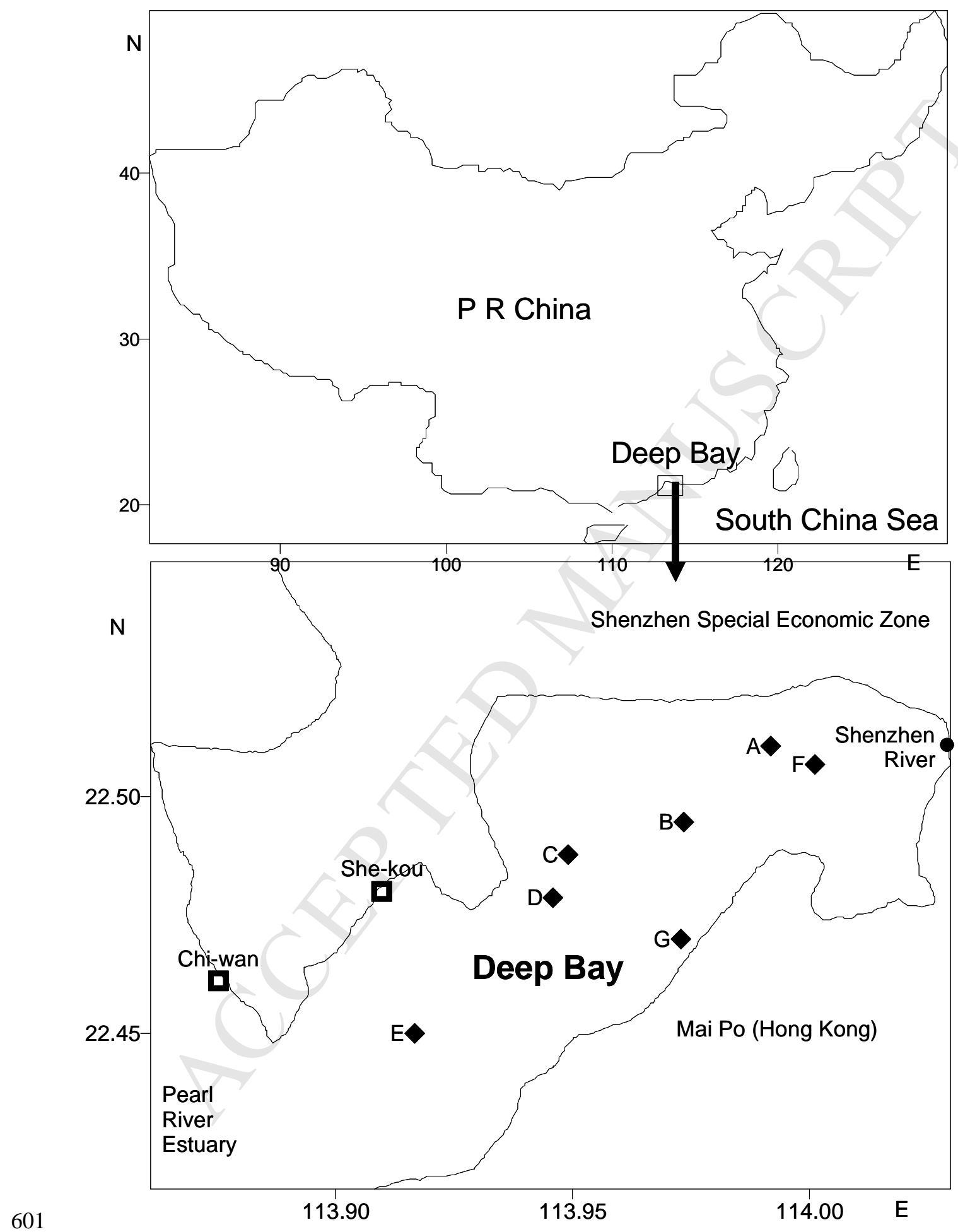


602 Fig. 2. The PBDEs concentrations and $\delta^{15} \mathrm{~N}$ values in organisms collected from 603 Deep Bay.

604

605

606

607

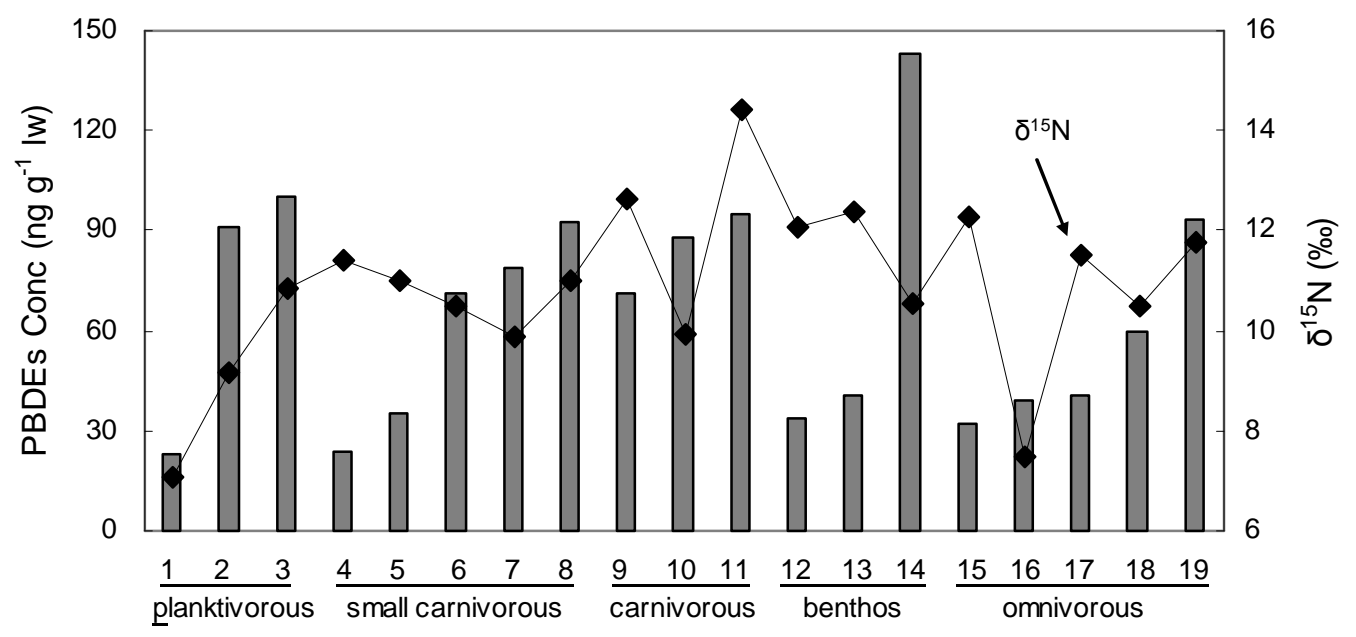

Planktivorous fish (1. Mugil cephalus, 2. Clupanodon punctatus, 3. Clupanodon thrissa), small carnivorous fish (4. Leiognathus ruconius, 5. Leiognathus bindus, 6. Ilisha elongate, 7. Thrissa dussumieri, 8. Sillago japonica), carnivorous fish (9. Dasyatis zugei, 10. Platycephalus indicus, 11. Inimicus cuvieri), benthos feeder (12. Nibea acuta, 13. Collichthys lucidus, 14. Cynoglossus robustus) and omnivorous organisms (15. Trypauchen vagina, 16. Portunus pubescens, 17. Polynemus sextarius, 18. Penaeus orientalis, 19. Glossogobius giuris). 
613 Fig. 3. The relationships between PBDEs concentrations and $\delta^{15} \mathrm{~N}$ values and lipid 614 percents in organisms from Deep Bay

615

616
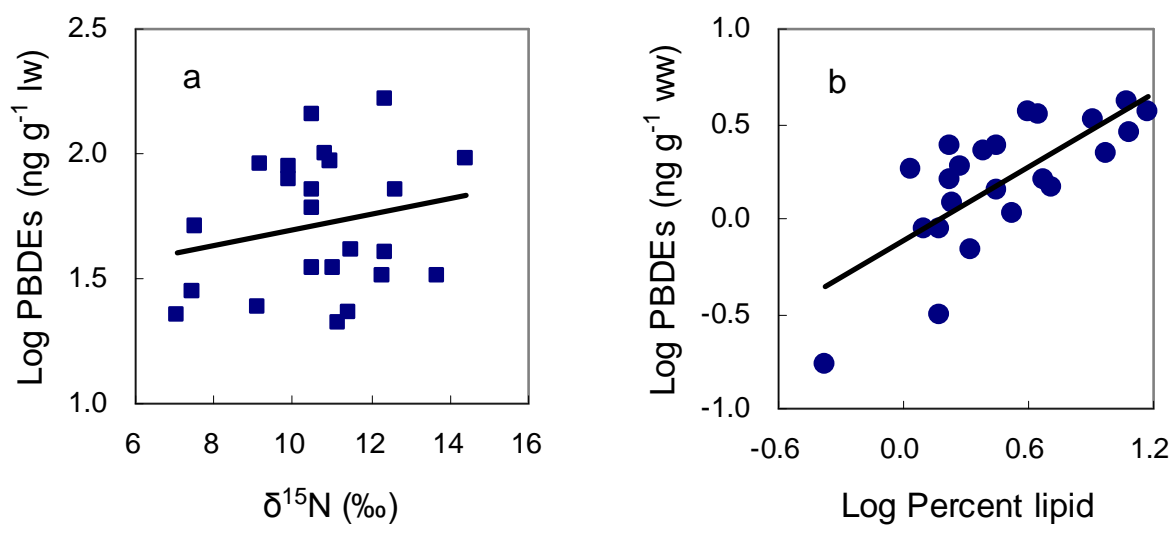
617 Fig. 4. PBDE concentrations in the sediment core by year of deposition (BDE209

618 was not included in the total PBDEs)

619

620
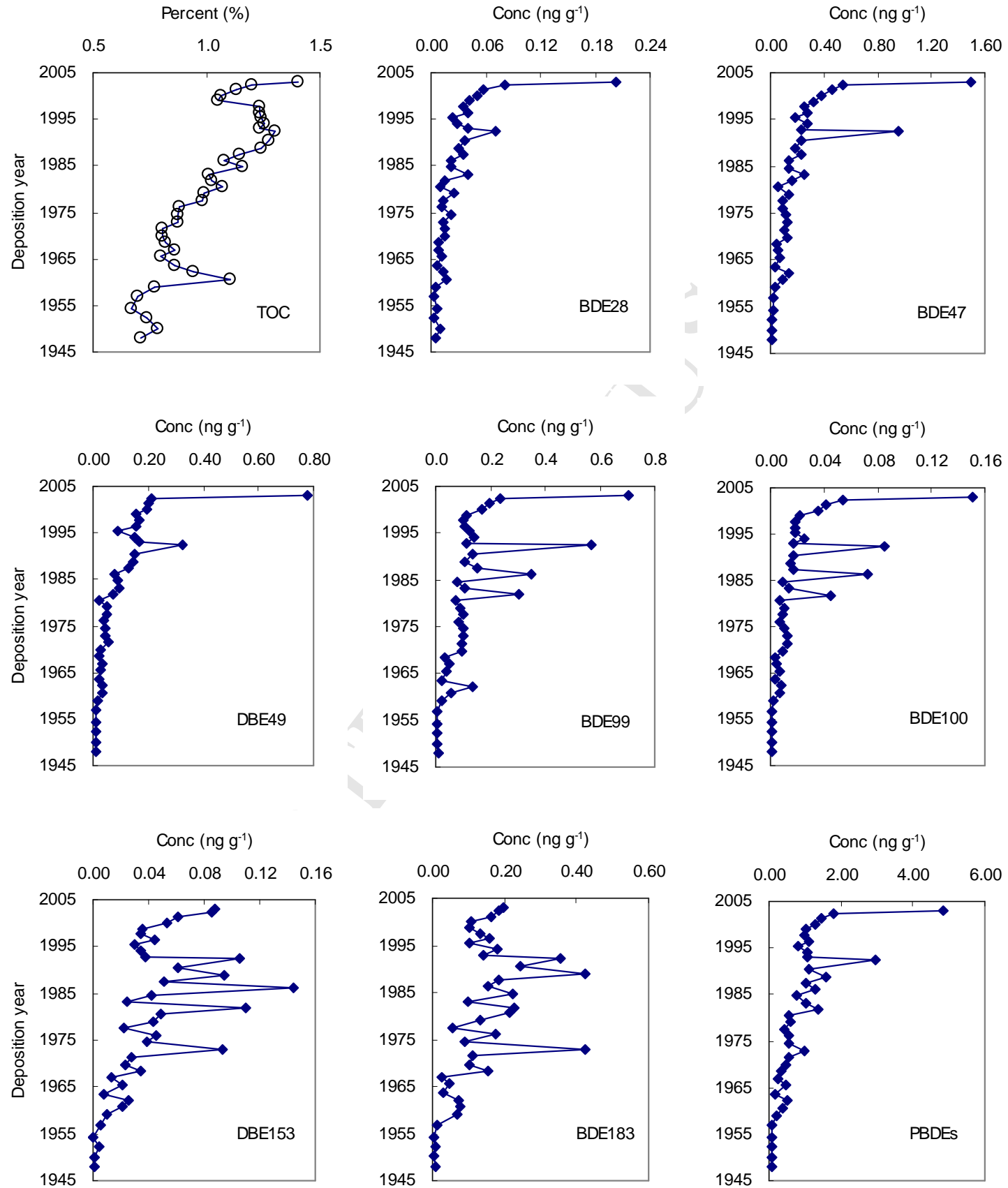
621 Fig. 5. The biota-sediment accumulation factors (BSAF) of PBDE congeners in 622 Deep Bay and their relation with the logarithm of octanol-water partition coefficient $623\left(K_{\text {ow }}\right)$

624

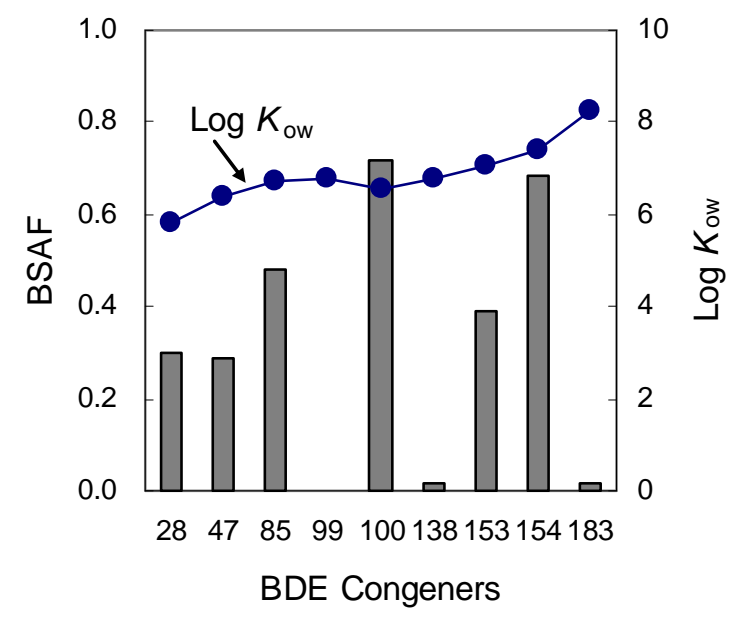

625 
628 AUTHORES:

629 ADDRESS:

630

631

632

633

634

635

636

637

638

639 JOURNAL:
Yao-Wen Qiu, Gan Zhang, Ling-Li Guo, Gene J Zheng, Shu-Qun Cai

Key Laboratory of Tropic Marine Environmental Dynamics, South

China Sea Institute of Oceanology, Chinese Academy of Sciences, Guangzhou 510301, China

State Key Laboratory of Organic Geochemistry, Guangzhou Institute of Geochemistry, Chinese Academy of Sciences, Guangzhou 510640, China

Department of Biology and Chemistry, Centre for Coastal Pollution and Conservation, City University of Hong Kong, Hong Kong, China

MANUSCRIPT TITLE: Bioaccumulation and Historical Deposition of Polybrominated Diphenyl Ethers (PBDEs) in Deep Bay, South China

Marine Environmental Research 
640

641

642

643

644

645

646

647

648

649

650

651

652

653

654

655 656

\section{List of Tables and Figure legends:}

\section{Tables:}

Table S1. Correlations between PBDE congeners and total organic carbon (TOC) in core sediments of Deep Bay, South China

Table S2. Correlations between PBDE congeners and lipid contents in organisms of Deep Bay, South China

\section{Figures:}

Fig. S1. Distribution of sedimentation age and excessive ${ }^{210} \mathrm{~Pb}$ activity in the sediment core B

Fig. S2. The percentage of PBDE congeners in organism and sediment of Deep Bay, South China

Fig. S3. Rotated factor pattern for PBDEs in core sediments of Deep Bay, South China

Fig. S4. Rotated factor pattern for PBDEs in organisms of Deep Bay, South China 
657 Table S1. Correlations between PBDE congeners and total organic carbon (TOC) in 658 core sediments of Deep Bay, South China

659

\begin{tabular}{|c|c|c|c|c|c|c|c|c|c|c|c|c|c|c|c|c|c|c|c|c|c|c|c|}
\hline BDE17 & & 1 & 0.97 & 0.63 & 0.92 & 0.84 & 0.97 & 1.00 & 0.95 & 0.26 & 0.87 & 0.90 & 0.86 & 0.84 & 0.88 & 0.61 & 0.67 & 0.46 & 0.58 & 0.26 & 0.38 & 0.70 & 0.95 \\
\hline BDE28 & & & 1 & 0.61 & 0.97 & 0.90 & 0.96 & 0.98 & 0.98 & 0.21 & 0.89 & 0.94 & 0.90 & 0.83 & 0.89 & 0.61 & 0.65 & 0.45 & 0.55 & 0.21 & 0.32 & 0.69 & 0.94 \\
\hline BDE32 & & & & 1 & 0.62 & 0.57 & 0.62 & 0.64 & 0.60 & 0.14 & 0.60 & 0.52 & 0.56 & 0.57 & 0.57 & 0.41 & 0.47 & 0.35 & 0.34 & 0.14 & 0.39 & 0.49 & 0.63 \\
\hline BDE35 & & & & & 1 & 0.90 & 0.92 & 0.94 & 0.97 & 0.16 & 0.87 & 0.94 & 0.92 & 0.78 & 0.84 & 0.65 & 0.65 & 0.44 & 0.48 & 0.21 & 0.36 & 0.74 & 0.90 \\
\hline BDE37 & & & & & & 1 & 0.81 & 0.86 & 0.90 & 0.38 & 0.76 & 0.83 & 0.82 & 0.69 & 0.76 & 0.71 & 0.64 & 0.48 & 0.54 & 0.46 & 0.39 & 0.68 & 0.85 \\
\hline BDE47 & & & & & & & 1 & 0.97 & 0.93 & 0.19 & 0.84 & 0.88 & 0.84 & 0.90 & 0.92 & 0.54 & 0.66 & 0.50 & 0.60 & 0.18 & 0.39 & 0.69 & 0.96 \\
\hline BDE49 & & & & & & & & 1 & 0.97 & 0.26 & 0.88 & 0.91 & 0.88 & 0.85 & 0.89 & 0.62 & 0.67 & 0.47 & 0.58 & 0.24 & 0.37 & 0.70 & 0.96 \\
\hline BDE66 & & & & & & & & & 1 & 0.21 & 0.90 & 0.95 & 0.92 & 0.81 & 0.88 & 0.66 & 0.65 & 0.46 & 0.52 & 0.24 & 0.32 & 0.70 & 0.92 \\
\hline BDE71 & & & & & & & & & & 1 & 0.17 & 0.05 & 0.12 & 0.16 & 0.14 & 0.42 & 0.22 & 0.30 & 0.34 & 0.68 & 0.43 & 0.23 & 0.32 \\
\hline BDE75 & & & & & & & & & & & 1 & 0.91 & 0.93 & 0.72 & 0.79 & 0.65 & 0.56 & 0.27 & 0.27 & 0.15 & 0.13 & 0.67 & 0.80 \\
\hline BDE77 & & & & & & & & & & & & 1 & 0.92 & 0.73 & 0.83 & 0.63 & 0.54 & 0.30 & 0.38 & 0.12 & 0.13 & 0.65 & 0.83 \\
\hline BDE85 & & & & & & & & & & & & & 1 & 0.78 & 0.85 & 0.72 & 0.67 & 0.38 & 0.36 & 0.20 & 0.20 & 0.78 & 0.84 \\
\hline BDE99 & & & & & & & & & & & & & & 1 & 0.97 & 0.46 & 0.83 & 0.73 & 0.74 & 0.15 & 0.47 & 0.80 & 0.94 \\
\hline BDE100 & & & & & & & & & & & & & & & 1 & 0.53 & 0.83 & 0.69 & 0.73 & 0.16 & 0.38 & 0.80 & 0.94 \\
\hline BDE119 & & & & & & & & & & & & & & & & & 0.46 & 0.28 & 0.26 & 0.70 & 0.30 & 0.67 & 0.60 \\
\hline BDE138 & & & & & & & & & & & & & & & & & & 0.82 & 0.79 & 0.31 & 0.54 & 0.89 & 0.79 \\
\hline BDE153 & & & & & & & & & & & & & & & & & & 1 & 0.88 & 0.36 & 0.78 & 0.70 & 0.68 \\
\hline BDE154 & & & & & & & & & & & & & & & & & & & 1 & 0.36 & 0.63 & 0.61 & 0.72 \\
\hline BDE166 & & & & & & & & & & & & & & & & & & & & 1 & 0.54 & 0.43 & 0.32 \\
\hline BDE183 & & & & & & & & & & & & & & & & & & & & & 1 & 0.55 & 0.55 \\
\hline BDE190 & & & & & & & & & & & & & & & & & & & & & & 1 & 0.80 \\
\hline PBDEs & & & & & & & & & & & & & & & & & & & & & & & 1 \\
\hline
\end{tabular}

661

$662 * \rho<0.01$ as coefficient is larger than 0.40 , while $\rho<0.05$ as coefficient ranges

663 0.30 0.40 (n=38). Principal Component Analysis (PCA) was performed to get the

664 rotated factor pattern of PBDEs in core sediment using varimax with Kaiser 665 normalization. 
666 Table S2. Correlations between PBDE congeners and lipid contents in organisms of 667 Deep Bay, South China

668

\begin{tabular}{|c|c|c|c|c|c|c|c|c|c|c|c|c|c|c|c|c|c|}
\hline & Lipid & BDE3 & BDE15 & BDE28 & BDE47 & BDE60 & BDE85 & BDE100 & BDE99 & BDE154 B & BDE153 & BDE138 & 3 BDE183 & BDE197 & BDE207 & BDE209 & 9 PBDEs \\
\hline Lipid & 1 & 0.12 & 0.65 & 0.17 & 0.52 & 0.56 & 0.50 & 0.33 & 0.12 & 0.29 & 0.58 & 0.12 & 0.54 & 0.54 & 0.32 & 0.29 & 0.69 \\
\hline BDE 3 & & 1 & -0.20 & -0.14 & -0.40 & 0.51 & -0.10 & 0.24 & 1.00 & -0.20 & 0.53 & 1.00 & 0.62 & -0.16 & -0.36 & -0.28 & -0.17 \\
\hline BDE15 & & & 1 & 0.36 & 0.54 & 0.15 & 0.18 & -0.02 & -0.20 & 0.08 & 0.16 & -0.20 & 0.14 & 0.39 & 0.56 & 0.66 & 0.56 \\
\hline BDE28 & & & & 1 & 0.38 & -0.02 & 0.33 & -0.03 & -0.14 & -0.02 & 0.09 & -0.14 & -0.13 & 0.07 & 0.37 & 0.45 & 0.54 \\
\hline BDE47 & & & & & 1 & -0.06 & 0.59 & -0.06 & -0.40 & 0.47 & 0.10 & -0.40 & 0.03 & 0.56 & 0.68 & 0.60 & 0.85 \\
\hline BDE60 & & & & & & 1 & 0.12 & 0.72 & 0.51 & -0.01 & 0.92 & 0.51 & 0.62 & 0.46 & -0.20 & -0.09 & 0.34 \\
\hline BDE85 & & & & & & & 1 & 0.10 & -0.10 & 0.74 & 0.34 & -0.10 & 0.20 & 0.54 & 0.23 & 0.29 & 0.74 \\
\hline BDE100 & & & & & & & & 1 & 0.24 & -0.06 & 0.71 & 0.24 & 0.35 & 0.47 & -0.25 & 0.00 & 0.32 \\
\hline BDE99 & & & & & & & & & 1 & -0.20 & 0.53 & 1.00 & 0.62 & -0.16 & -0.36 & -0.28 & -0.17 \\
\hline BDE154 & & & & & & & & & & 1 & 0.16 & -0.20 & 0.14 & 0.44 & 0.41 & 0.25 & 0.50 \\
\hline BDE153 & & & & & & & & & & & 1 & 0.53 & 0.68 & 0.57 & -0.12 & 0.04 & 0.51 \\
\hline BDE138 & & & & & & & & & & & & & 0.62 & -0.16 & -0.36 & -0.28 & -0.17 \\
\hline BDE183 & & & & & & & & & & & & & 1 & 0.22 & -0.17 & -0.08 & 0.24 \\
\hline BDE197 & & & & & & & & & & & & & & 1 & 0.24 & 0.36 & 0.74 \\
\hline BDE207 & & & & & & & & & & & & & & & 1 & 0.71 & 0.54 \\
\hline BDE209 & & & & & & & & & & & & & & & & 1 & 0.60 \\
\hline PBDEs & & & & & & & & & & & 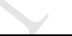 & & & & & & 1 \\
\hline
\end{tabular}


670 Fig. S1. Distribution of sedimentation age and excessive ${ }^{210} \mathrm{~Pb}$ activity in the sediment 671 core B
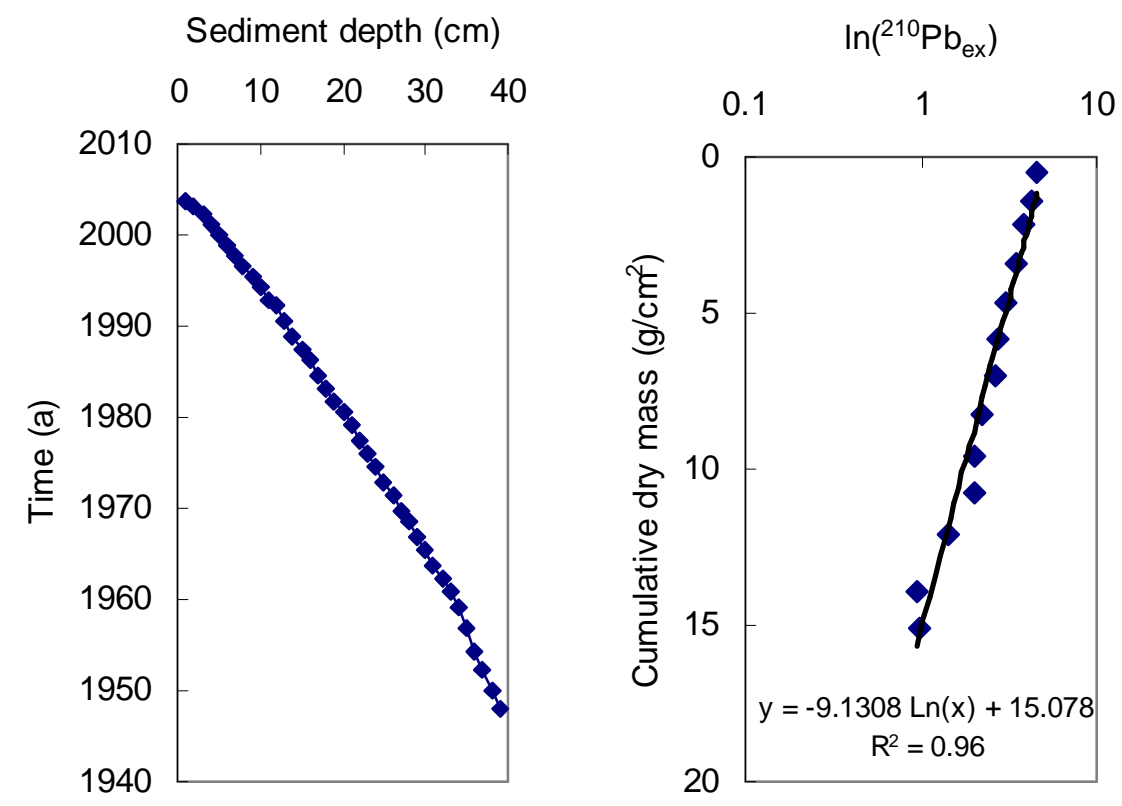

672 
673 Fig. S2. The percentage of PBDE congeners in organism and sediment of Deep Bay,

674 South China *

675

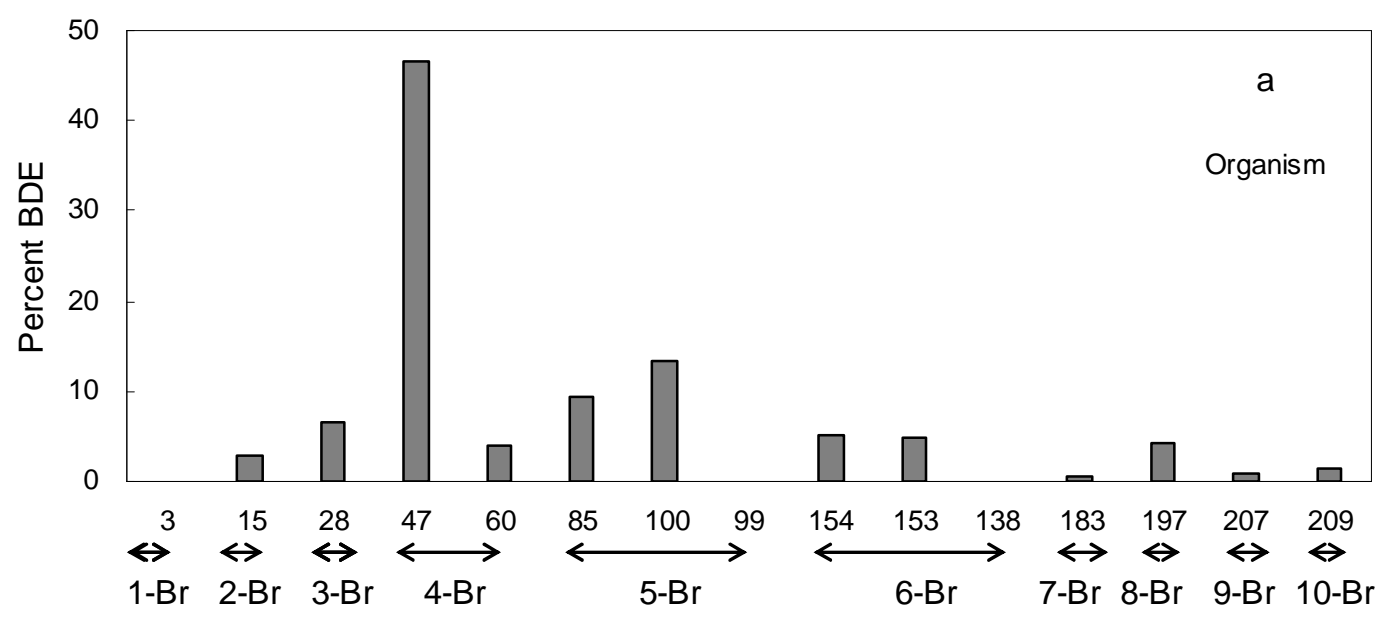

676

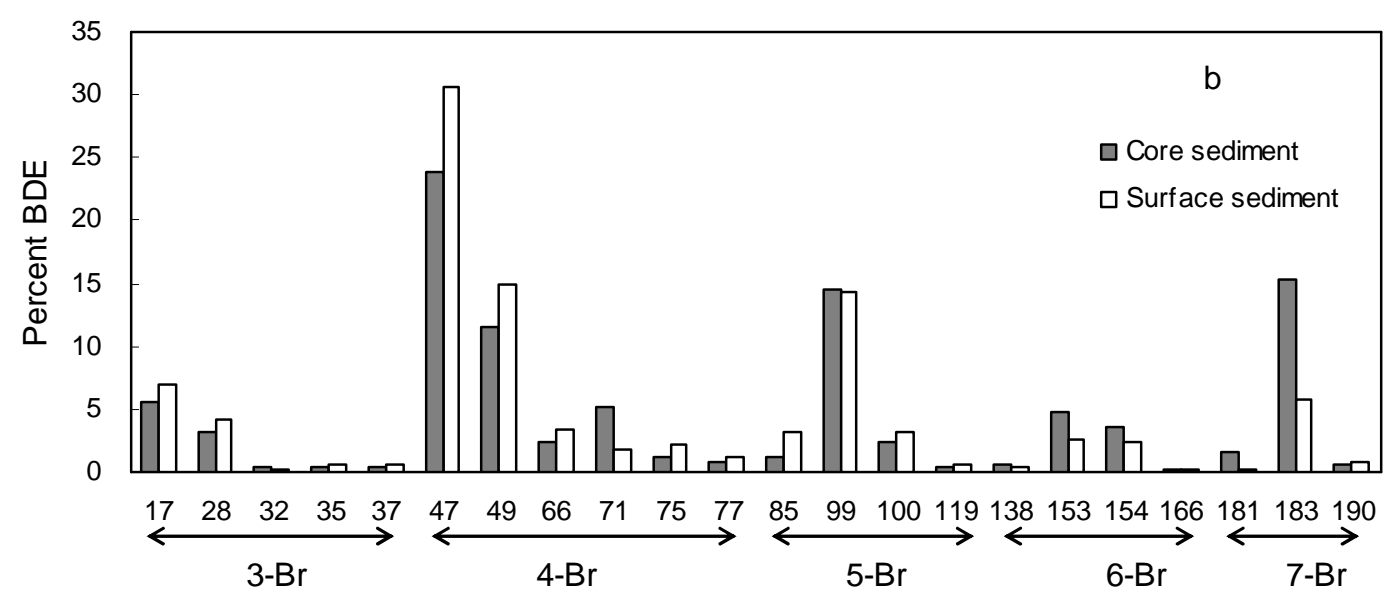

677

$678 *$ It should be noted that BDE-209 was not included in sediment. 
679 Fig. S3. Rotated factor pattern for PBDEs in core sediments of Deep Bay, South 680 China

681

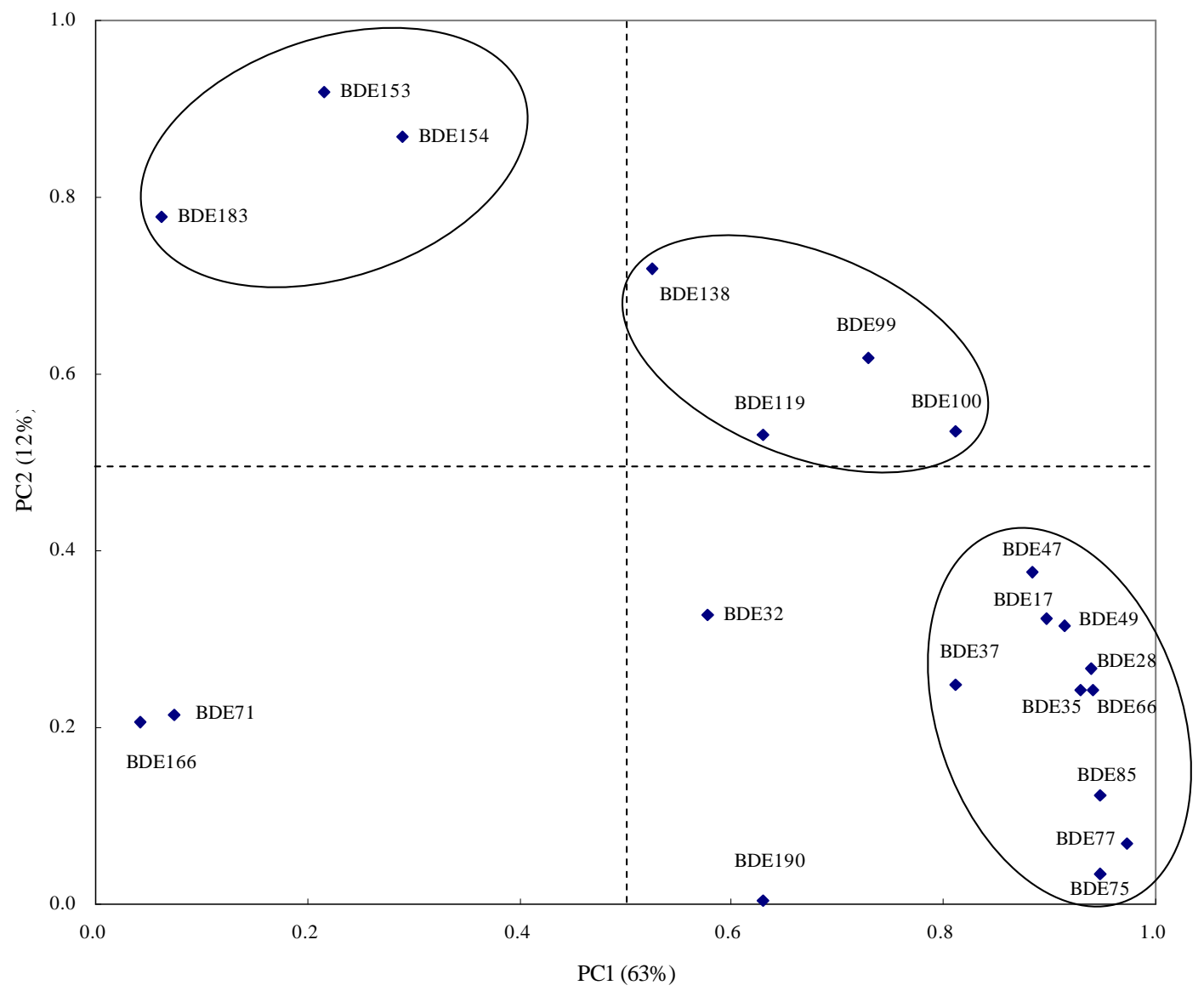

682 
684

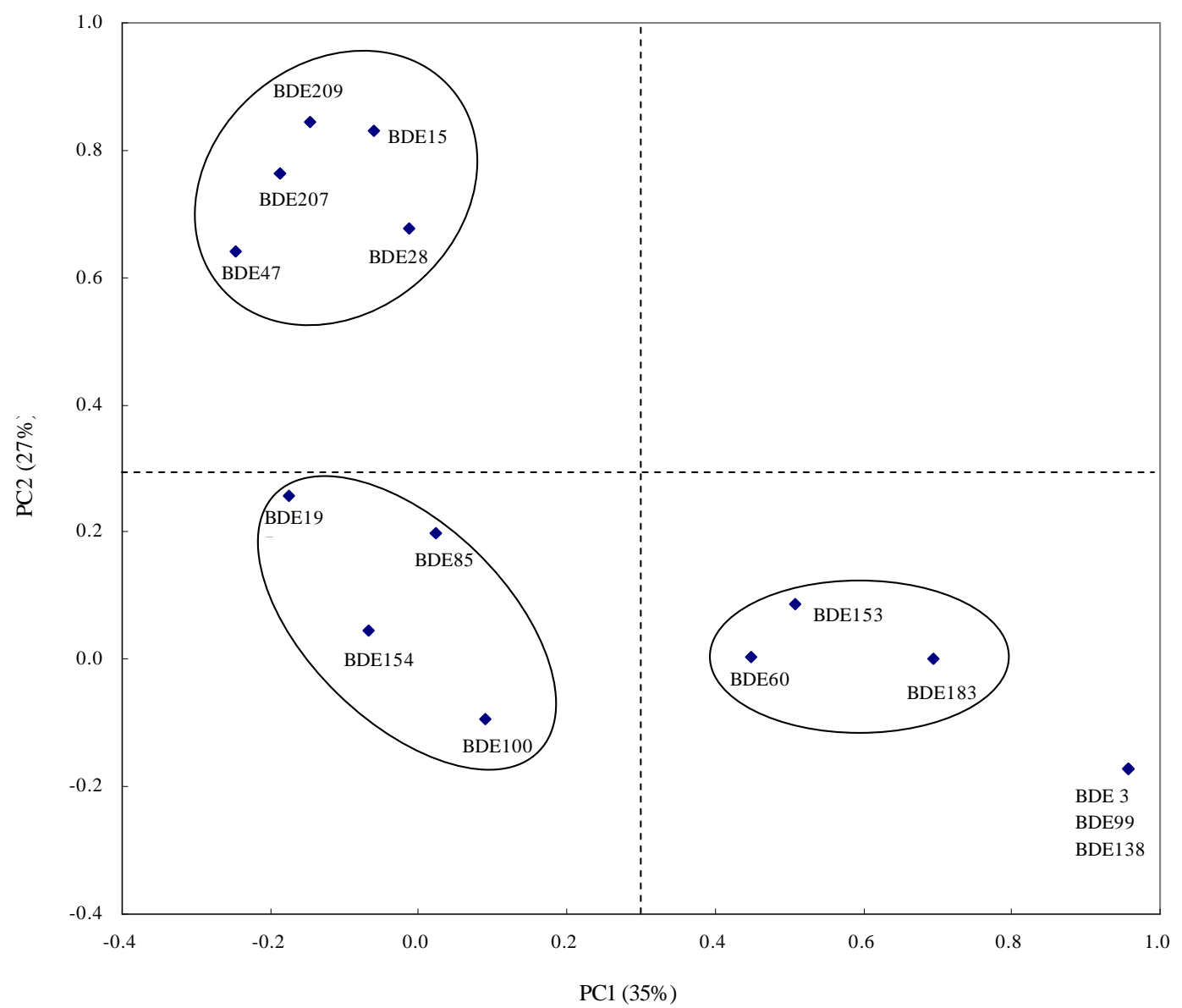

685 